\title{
OPTIMASI FITUR LAYANAN SISTEM PENJADWALAN PERKULIAHAN BERBASIS MOBILE DI UNIVERSITAS DARUSSALAM GONTOR
}

\author{
Faisal R Pradhana ${ }^{1}$, Lukman Effendi ${ }^{2}$, Lutfi Ahmad ${ }^{3}$ \\ 1,2,3 Program Studi Teknik Informatika, Universitas Darussalam Gontor Ponorogo \\ Email: ${ }^{1}$ faisalrezapradhana @ unida.gontor.ac.id, ${ }^{2}$ lukman @ unida.gontor.ac.id, ${ }^{3}$ lutfiahmad@unida.gontor.ac.id
}

(Naskah masuk: 14 Oktober 2020, diterima untuk diterbitkan: 25 Desember 2020)

\begin{abstract}
Abstrak
Universitas Darussalam Gontor telah menerapkan sistem penjadwalan perkuliahan secara online berbasis website dan terbukti sangat membantu dalam proses pengelolaan jadwal perkuliahan, namun hal tersebut tidak berlaku didalam hal pendistribusian data, masalah tersebut muncul dikarenakan akses yang terbatas dan belum adanya layanan pendistribusian data otomatis yang dapat memberikan notifikasi langsung kepada dosen pengampu dan mahasiswa. Media pada aplikasi ini berbasis mobile android dan menggunakan pendekatan model waterfall pada perancangannya. Data Jadwal perkuliahan dan kalender akademik diambil langsung dari sistem penjadwalan perkuliahan Universitas Darussalam Gontor. Aplikasi penjadwalan perkuliahan ini ditujukan untuk memberikan informasi jadwal perkuliahan seluruh program studi dan kalender akademik dengan data yang terintegrasi, serta memiliki layanan update jadwal secara otomatis sehingga mengoptimalkan pendistribusian jadwal perkuliahan kepada seluruh dosen dan mahasiswa. Pengujian aplikasi dilakukan melalui dua cara, yaitu uji kesesuaian pada berbagai perangkat dan seri android menghasilkan kesesuaian aplikasi pada perangkat berukuran minimal 4,5 inchi serta android kitkat sebagai versi android terendah yang mendukung jalannya aplikasi. Uji kedua dilakukan melalui penyebaran kuesioner kepada staff biro akademik dan kemahasiswaan menghasilkan nilai rata-rata $92 \%$, bapak ibu dosen pengampu mata kuliah menghasilkan nilai rata-rata $80 \%$, dan hasil penilaian sample mahasiswa menghasilkan 95\% rata-rata. Data hasil kuesioner menunjukkan tingkat kesesuaian fitur aplikasi dengan kebutuhan pengguna. Aplikasi ini bukan sebagai pengganti sistem penjadwalan perkuliahan yang sudah ada, melainkan lebih sebagai pelengkap fitur yang sebelumnya terbatas serta membantu proses layanan pendistribusian data menjadi lebih optimal.
\end{abstract}

Kata kunci: Aplikasi Mobile, Optimaliasi Fitur, Sistem Penjadwalan

\section{FEATURES OPTIMIZATION OF MOBILE-BASED LECTURES SCHEDULING SYSTEM AT DARUSSALAM GONTOR UNIVERSITY}

\begin{abstract}
University of Darussalam Gontor has implemented a website-based online lecture scheduling system and proven to be very helpful in the process of managing lecture schedules. However, this does not apply in terms of data distribution, the problem exist due to limited access and the absence of automatic data distribution services that can provide direct notifications to lecturers and students. The application media is designed based on mobile android and uses the waterfall model approach in its design. Lecture schedule data and academic calendar are taken directly from the lecture scheduling system of the University of Darussalam Gontor. The lecture scheduling application is intended to provide lecture schedule information and academic calendars for all majors with integrated data, featured with automatic schedule update service, in order to optimize the delivery of lecture schedules to all lecturers and students. Application testing is carried out in two ways, namely compatibility testing on various devices and Android versions, resulting in application compatibility on devices measuring at least 4,5 inches and Android Kitkat as the lowest Android version that supports application running. The second test was carried out by distributing questionnaires to the staff of the academic bureau and student affairs, which resulted in an average score of $92 \%$, the lecturers produced an average score of $80 \%$, and the results of student assessments produced an average of 95\%. The questionnaire result data shows the level of suitability of application features with user needs. This application is not a substitute for the existing lecture scheduling system, but rather as a complement to previously limited features and to help the data distribution service process more optimally.
\end{abstract}

Keywords: Mobile application, feature optimization, , scheduling system. 


\section{PENDAHULUAN}

Universitas Darussalam Gontor (UNIDA Gontor) melalui Biro Administrasi dan Akademik Kemahasiswaan (BAAK), berupaya untuk mengoptimalkan penggunaan sarana dan prasarana ruang di Universitas Darussalam Gontor. Salah satu caranya dengan menerapkan sistem penjadwalan perkuliahan secara online dan terbukti sangat membantu dalam proses pengelolaan jadwal perkuliahan, namun terdapat beberapa kelemahan dari sistem yang telah berjalan selama ini adalah belum cukup membantu dalam hal pendistribusian jadwal perkuliahan, akses menuju sistem penjadwalan terbatas hanya untuk penjadwal, dan sistem informasi akademik dinilai belum mobile responsive.

Dokumen Aplikasi dirancang menggunakan platform android yang diaplikasikan pada smartphone, target pengguna aplikasi yang dirancang ini adalah seluruh mahasiswa dan dosen Universitas Darussalam Gontor yang mayoritas memiliki smartphone android sebagai alat komunikasi seharihari. Android dipilih sebagai basis aplikasi ini karena android merupakan sistem operasi yang paling banyak digunakan oleh masyarakat dunia saat ini, aplikasi android telah digunakan untuk berbagai keperluan, seperti hiburan, pendidikan, bisnis, kesehatan dan lain sebagainya[1]. Tercatat, aplikasi android telah digunakan oleh lebih dari 170 negara di dunia dan tercatat $70 \%$ penggunaan sistem operasi smartphone. Keunggulan lain dari android adalah memiliki lisensi open source sehingga para pengembang memiliki kebebasan dalam hal pengembangan dan inovasi [2]. Dipilihnya sistem operasi android sebagai basis aplikasi juga sejalan dengan peningkatan pengguna smartphone di dunia yang mengalami peningkatan lebih dari $60 \%$ penggunaan perangkat digital, hal ini menunjukkan bahwa smartphone merupakan perangkat digital yang paling banyak digunakan. perangkat dibandingkan dengan perangkat lain di dunia [3]. Berdasarkan berbagai fakta di atas, diharapkan aplikasi ini dapat menjadi solusi terbaik dan jawaban atas segala kebutuhan.

Pada penelitian yang lain[4] tentang aplikasi penjadwalan berbasis webmobile di sebuah sekolah menengah terbukti dapat membantu dalam memperlancar jalannya belajar dan mengajar serta mempermudah mendapatkan jadwal pelajaran, aplikasi dapat diterima dan disukai oleh $70 \%$ calon pengguna dan hanya mendapatkan kritikan terkait desain aplikasi. Referensi yang lain[5] menyebutkan didalam penelitian mereka terkait penggunaan mobile push notification dalam penyampaian jadwal perkuliahan mahasiswa berbasis android, bahwa penggunaan aplikasi berbasis mobile terbukti dapat mempermudah penyampaian informasi kepada mahasiswa terkait jadwal perkuliahan secara cepat sehingga mahasiswa tidak perlu mengkhawatirkan ketinggalan pengumuman penting terkait kegiatan perkuliahan.

Referensi lain[6] menyebutkan hasil analisis mereka terkait aplikasi jadwal perkuliahan berbasis android, bahwa ada 4 hal yang menjadi aspek standar dalam menentukan tingkat keberhasilan sebuah aplikasi penjadwalan yang dirancang, yaitu functional suitability, compatibility, usability, dan performance efficiency. Pada analisis yang telah dilakukan, dihasilkan nilai $100 \%$ pada aspek functional suitability, $100 \%$ pada aspek compatibility, dan $79,63 \%$ pada aspek usability. Sedangkan, pengujian performance efficiency mendapatkan hasil sebesar 2,048 detik untuk launching aplikasi, berdasarkan hasil analisis tersebut dapat dinyatan bahwa aplikasi penjadwalan berbasis android layak dan mendapatkan predikat sangat puas. Selain itu, aplikasi penjadwalan juga diterapkan pada bidang kesehatan [14] dan [15].

Diharapkan dengan adanya aplikasi ini dapat sangat membantu dan memudahkan proses pendistribusian atau penyampaian jadwal perkuliahan sehingga menjadi lebih efektif. Ditambah dengan kemampuan smartphone android yang selalu terkoneksi dengan internet, sehingga bisa membantu dosen dan mahasiswa untuk memantau jadwal kuliah secara real time.

\section{METODE PENELITIAN}

Perancangan aplikasi ini ini menggunakan metode Software Development Life Cycle (SDLC), melalui alur pendekatan waterfall[7]. teknik ini juga pernah diterapkan oleh [8]. dalam perancangannya dikarenakan kesesuaian metode tersebut dengan kebutuhan dimana ketika diverifikasi kelemahan metode dan aspek kebutuhan sudah jelas tercatat pada aplikasi penjadwalan yang telah ada sebelumnya. Gambar 1 menjelaskan terkait tahapn-tahapan yang ada pada model waterfall.

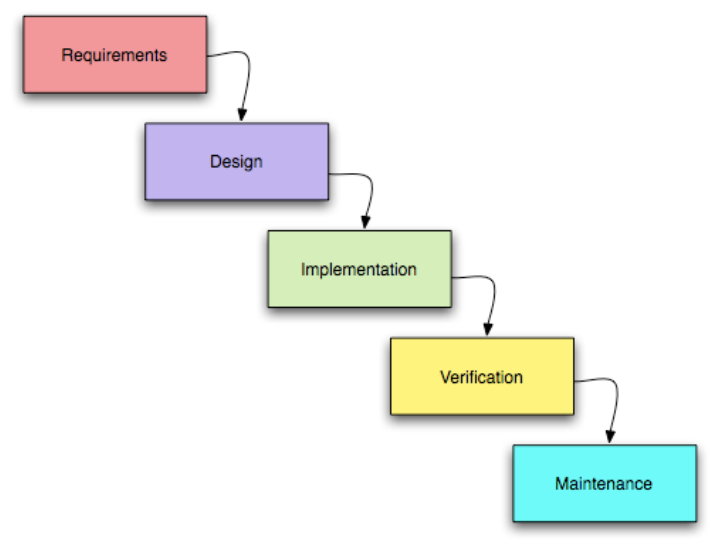

Gambar 1. Model Waterfall

Model waterfall memiliki 5 tahapan, yaitu tahap analisis kebutuhan (requirements), desain, 
implentasi, verifikas dan perawatan (maintenance), detail dari masing-masing tahapan akan dijelaskan pada bab hasil dan pembahasan.

\section{HASIL DAN PEMBAHASAN}

\subsection{Requirement}

Jadwal perkuliahan yang dipakai sesuai dengan Standar Operasional Prosedur (SOP) penjadwalan perkuliahan di Universitas Darussalam Gontor, data jadwal perkuliahan yang digunakan merupakan data jadwal kuliah pada semester gasal (tahun ajaran 20192020).

Tabel 1 merupakan hasil dari tahap penjajakan yang telah dilakukan, dimulai dari perumusan masalah dan solusi teknologi yang akan digunakan dalam pengembangan fitur layanan penjadwalan perkuliahan berbasis mobile android ini. Penggalian kebutuhan dilakukan melalui tahap observasi kepada Biro Administrasi dan Akademik Kemahasiswaan (BAAK) UNIDA Gontor, yang memandang perlunya pengembangan layanan sistem penjadwalan perkuliahan berbasis mobile, karena tuntutan akan kebutuhan pendistribusian data perkuliahan yang dapat diakses dengan cepat dan real time.

Tabel 1. Kebutuhan Pengembangan Aplikasi

\begin{tabular}{|c|c|c|}
\hline No & Kegiatan & Hasil \\
\hline 1 & $\begin{array}{l}\text { Identifikasi } \\
\text { Masalah }\end{array}$ & $\begin{array}{l}\text { - Terdapat beberapa dosen dan } \\
\text { mahasiswa yang terlambat dalam } \\
\text { mendapatkan informasi jadwal } \\
\text { perkuliahan. } \\
\text { - Jadwal perkuliahan yang } \\
\text { disebarkan melalui hard copy di } \\
\text { papan pengumuman kantor } \\
\text { BAAK dirasa kurang efisien. }\end{array}$ \\
\hline 2 & $\begin{array}{l}\text { Konten/isi dari } \\
\text { aplikasi }\end{array}$ & $\begin{array}{l}\text { Data jadwal perkuliahan dan } \\
\text { kalender akademik diambil dari } \\
\text { system penjadwalan perkuliahan } \\
\text { yang dikelola oleh BAAK UNIDA } \\
\text { Gontor }\end{array}$ \\
\hline 3 & $\begin{array}{l}\text { Solusi yang } \\
\text { ditawarkan }\end{array}$ & $\begin{array}{l}\text { Optimasi fitur layanan yang ada } \\
\text { pada system penjadwalan } \\
\text { perkuliahan yang sudah ada. }\end{array}$ \\
\hline 4 & $\begin{array}{l}\text { Teknologi yang } \\
\text { digunakan }\end{array}$ & $\begin{array}{l}\text { Aplikasi penjadwalan berbasis } \\
\text { Mobile Android }\end{array}$ \\
\hline
\end{tabular}

Pada tahap penjajakan ini, juga dilakukan analisis terhadap kebutuhan data yang akan ditampilkan pada rancangan aplikasi ini. Berikut adalah hasil analisis kebutuhan data yang akan dibangun.

1. Data Mata kuliah

2. Data Dosen

3. Data Mahasiswa

4. Data Fakultas

5. Data Program Studi

6. Data Waktu kuliah

7. Data Kalender akademik

\subsection{Design}

Setelah mengetahui detail kebutuhan dan model konten yang akan dirancang, maka langkah selanjutnya adalah pembuatan alur langkah-langkah penggunaan aplikasi. Dimulai sari perancangan diagram arsitektur sistem, use case diagram dan activity diagram.

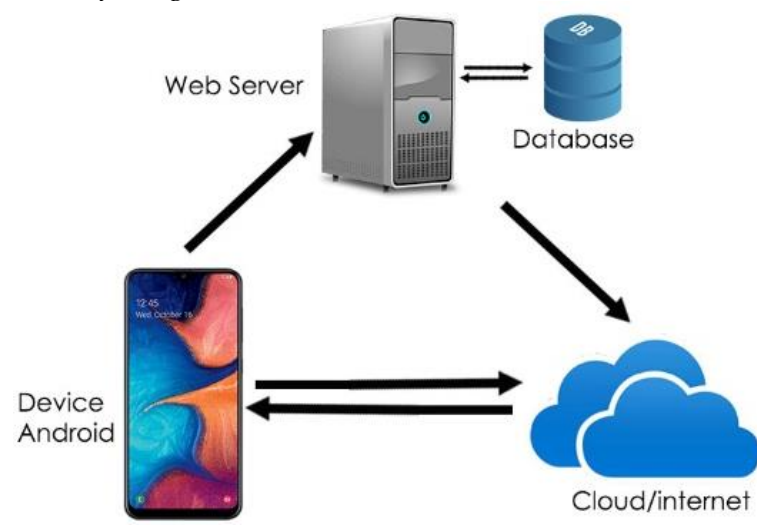

Gambar 2. Diagram Arsitektur Sistem

Gambar 2 merupakan Diagram Arsitektur Sistem. arsitektur sistem adalah gambaran secara garis besar terkait cara kerja sistem yang digambarkan melalui beberapa model yang saling berhubungan[9], dijelaskan hubungan antara system penjadwalan berbasis web dan mobile serta alur pendistribusian data yang dilakukan.

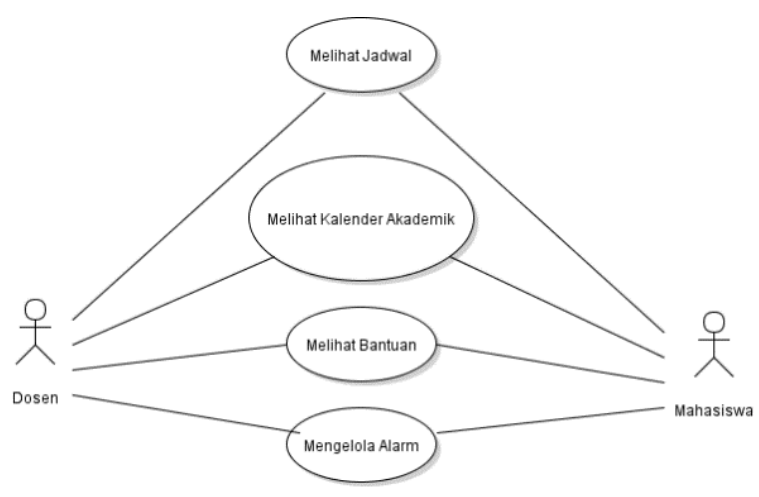

Gambar 3. Use Case Diagram aplikasi

Use case diagram[10] merupakan pemodelan behavior (kelakuan) dari sistem informasi yang akan dirancang. Pada gambar 3 merupakan gambar use case diagram aplikasi, dijelaskan bagaimana akses yang diberikan kepada dosen dan mahasiswa terhadap data yang didistribusikan.

Pada activity diagram aplikasi yang ditampilkan pada gambar 4, dijelaskan alur dan beberapa fitur aplikasi, terdapat beberapa menu yang ditampilkan dan dapat diakses, diantaranya splash screen, menu utama, menu jadwal, menu kalender, menu alarm, dan menu bantuan. Dijelaskan pula bagaimana alur penggunaan aplikasi dimulai dari start hingga keluar aplikasi. 


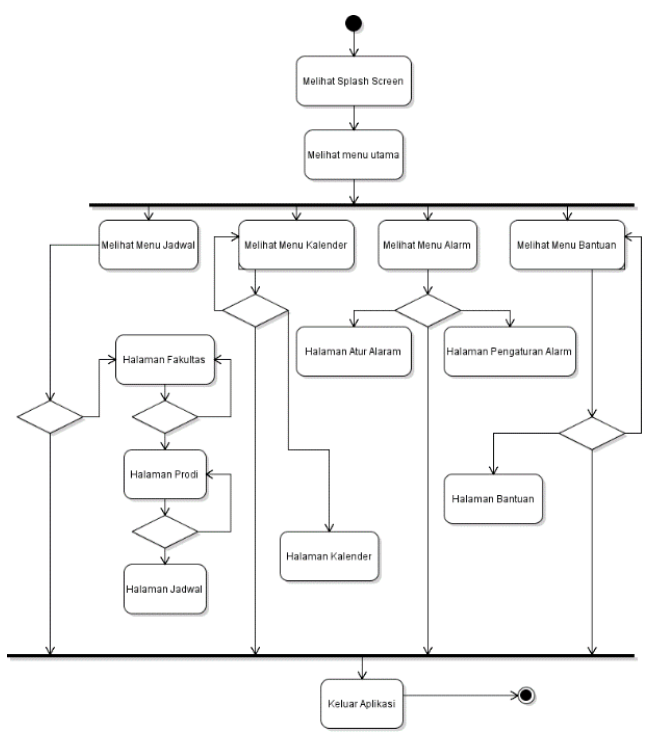

Gambar 4. Activity Diagram Aplikasi

\subsection{Implementation}
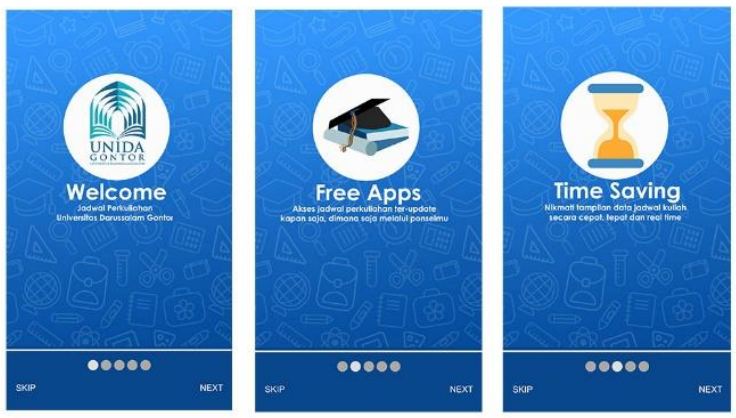

Gambar 5. Tampilan halaman splash screen

Gambar 5 menampilkan tampilan halaman splash screen atau halaman awal ketika pengguna membuka aplikasi untuk pertama kalinya, berisi ucapan selamat datang dan penjelasan terkait sifat aplikasi dan keuntungan yang didapatkan ketika menggunakan aplikasi.

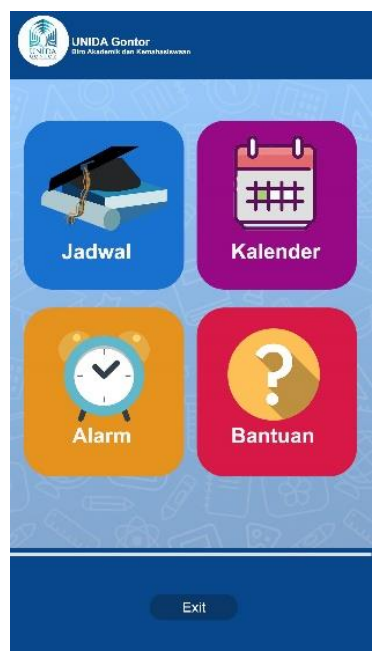

Gambar 6. Tampilan halaman menu utama

Tampilan halaman menu utama aplikasi ditunjukkan pada gambar 6 , dimana terdapat 4 pilihan menu didalamnya yaitu menu jadwal, menu kalender, menu alarm dan menu bantuan, ketika pengguna menekan salah satu tombol menu tersebut, maka akan otomatis diarahkan menuju data yang dinginkan.
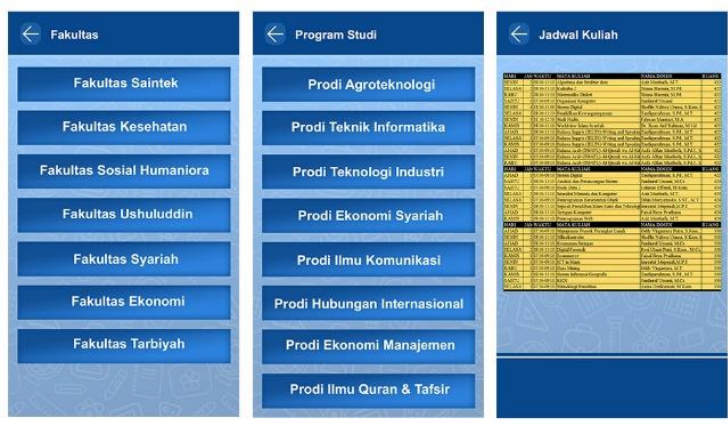

Gambar 7. Tampilan halaman menu jadwal

Gambar 7 merupakan tampilan halaman menu jadwal, ketika pengguna memilih menu jadwal maka akan diarahkan kepada halaman fakultas, setelah pengguna memilih fakultas yang sesuai, maka selanjutnya pengguna ditampilkan halaman program studi, dan ketika pengguna telah memilih program studi yang diinginkan, maka akan ditampilkan jadwal kuliah dari program studi tersebut. Tombol panah (arrow) pada kolom atas berfungsi untukkembali ke menu sebelumnya.
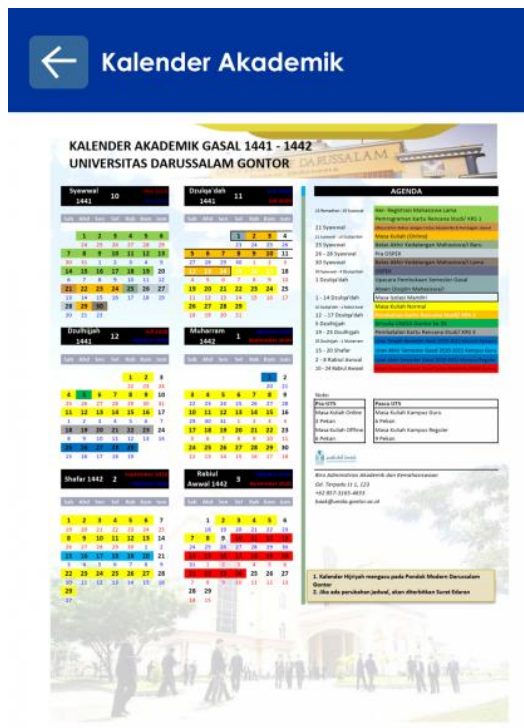

Gambar 8. Tampilan halaman kalender akademik

Pada Gambar 8 dijelaskan tampilan halaman kalender akademik, dimana pengguna dapat melihat jadwal kegiatan atau agenda kampus selama tahun ajaran yang berlangsung. Data sampel diambil dari kalender kegiatan akademik semester gasal tahun 
2019-2020 masehi atau 1441-1442 hijriyah di Universitas Darussalam Gontor.

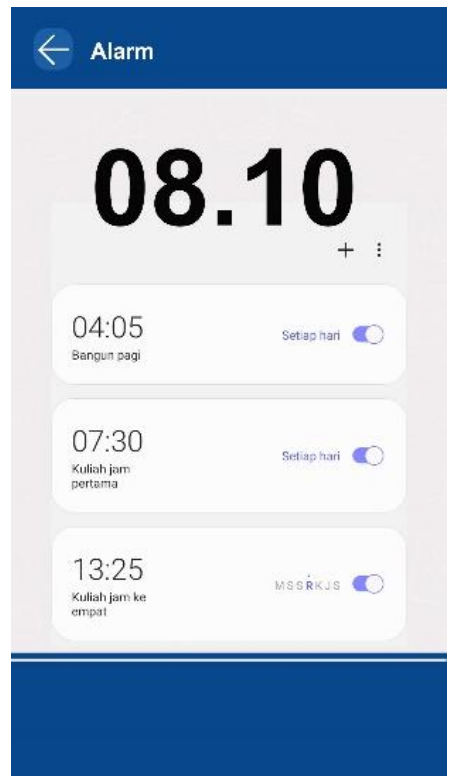

Gambar 9. Tampilan halaman alarm

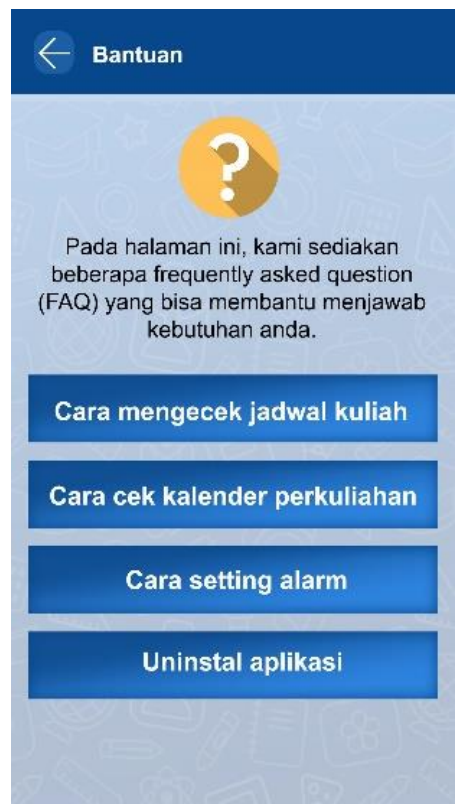

Gambar 10. Tampilan halaman bantuan

Pada Gambar 9 dan 10, dijelaskan tampilan dari halaman alarm dan halaman bantuan, pada halaman alarm, pengguna dapat mengelola alarm seperti mengatur waktu alarm dan nada alarm serta memuat tampilan waktu. Sementara pada halaman bantuan ditampilkan beberapa pertanyaan yang kemungkinan akan sering diajukan oleh para pengguna terkait aplikasi. Dengan adanya halaman bantuan tersebut diharapkan calon pengguna tidak akan mengalami kebingungan ketika menjalankan aplikasi tersebut.

\subsection{Verification}

Setiap aplikasi yang telah berhasil dirancang, pasti akan terdapat beberapa kekurangan didalamnya, sehingga perlu dilakukan pengujian agar dapat mengurangi tingkat kegagalan atau kesalahan yang ditimbulkan serta mengurangi kerugian baik dipihak developer maupun pengguna[11]. Pengujian atau validasi dilakukan merupakan suatu proses untuk memeriksa apakah perangkat lunak memenuhi spesifikasi dan tujuan yang dimaksudkan. Pada setiap tahap pengujian aplikasi, kualitas validasi yang akurat sangat dibutuhkan, sehingga dapat membantu pemilik maupun pengguna dalam keakuratan data aplikasi[12]. Pengujian pada plikasi kali ini dilakukan dengan cara menerapkan test tes kesuaian aplikasi terhadap perangkat smartphone android, test fungsional setiap fitur aplikasi dan test kesesuaian fungsi aplikasi terhadap calon pengguna.

Table 1. Hasil tes kesesuaian aplikasi terhadap perangkat

\begin{tabular}{llll}
\multicolumn{4}{c}{ smartphone android } \\
\hline No & \multicolumn{1}{c}{$\begin{array}{c}\text { Tipe } \\
\text { perangkat }\end{array}$} & $\begin{array}{c}\text { Layar } \\
\text { (inchi) }\end{array}$ & Hasil \\
\hline 1 & $\begin{array}{l}\text { Samsung A20 } \\
\text { (android 8.0 Oreo) }\end{array}$ & 6,4 & Berhasil \\
2 & $\begin{array}{l}\text { Lenovo A6000 } \\
\text { (android 4.4.4 KitKat) }\end{array}$ & 5.0 & Berhasil \\
3 & $\begin{array}{l}\text { Oppo F3 } \\
\text { (android 5.1 Lollipop) }\end{array}$ & 5.5 & Berhasil \\
4 & $\begin{array}{l}\text { Sony Xperia Z1 Compact } \\
\text { D5503 (android 4.3 Jelly } \\
\text { Bean) } \\
\text { Oppo Neo 7 } \\
\text { (android 5.1 Lollipop) }\end{array}$ & 4.0 & Gagal \\
6 & $\begin{array}{l}\text { Coolpad Roar A110 } \\
\text { (android 5.1 Lollipop) }\end{array}$ & 4,5 & Berhasil \\
7 & $\begin{array}{l}\text { Xiaomi MIA2 } \\
\text { (android 9.0 Pie) } \\
\text { Vivo V15 }\end{array}$ & 5,99 & Berhasil \\
(android 8.0 Oreo) & 6,5 & Berhasil \\
\hline
\end{tabular}

Tabel 4 menunjukkan Hasil tes kesesuaian aplikasi terhadap perangkat smartphone android dengan layar minimal 4,5 inchi, dan minimal diperlukan versi android 4.4.4 KitKat dalam menjalankan aplikasi ini. Selain pengujian kesesuaian perangkat, dilakukan pula pengujian terhadap fungsional fitur aplikasi, testing tersebut dilakukan dengan metode Black box, yang merupakan bentuk pengujian yang berfokus pada spesifikasi fungsional dari perangkat lunak, pada metode blackbox tester dapat mendefinisikan kumpulan kondisi input dan melakukan pengetesan pada spesifikasi fungsional program[13]. Test fungsional fitur ini memberikan hasil $100 \%$, sehingga dapat dikatakan bahwasanya aplikasi ini dapat dipakai dengan layak.

Pengujian selanjutnya dilakukan dengan memberikan kuesioner kepada 5 orang staff Biro Administrasi dan Akademik Kemahasiswaan (BAAK), dan mendapatkan skor rata-rata $92 \%$ pada tingkat kesesuaian fungsi aplikasi terhadap kebutuhan pengguna, data rekapan Hasil penyebaran kuesioner staff BAAK UNIDA Gontor dapat dilihat pada gambar 11 berikut. 


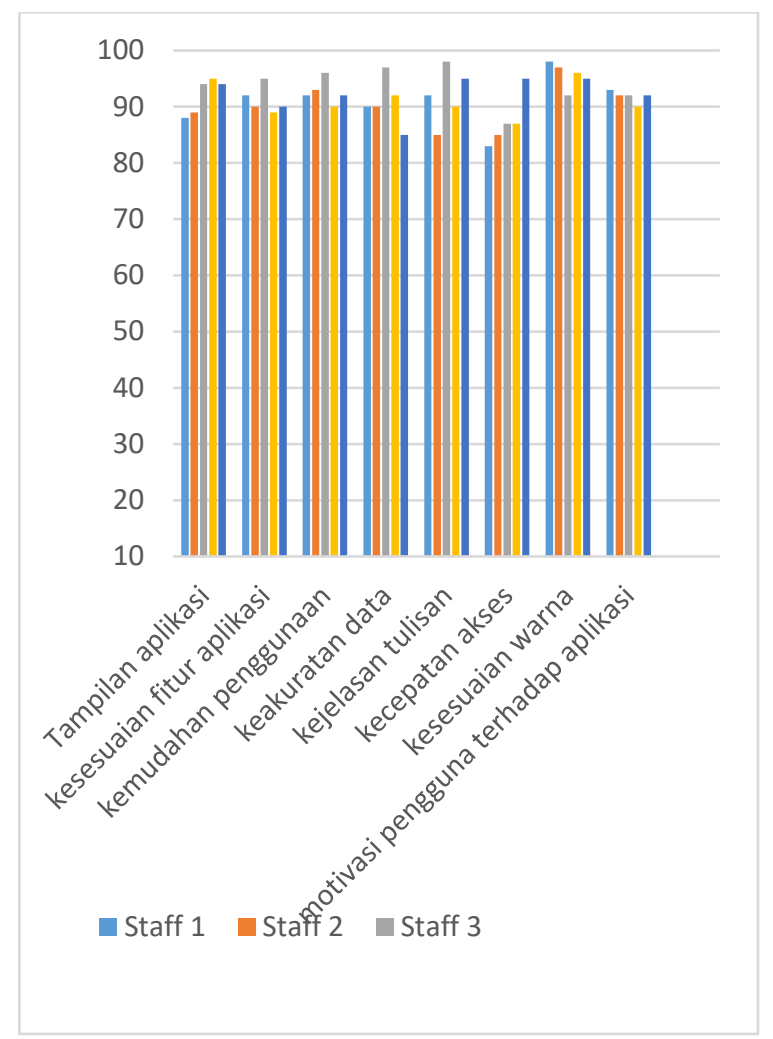

Gambar 11. Hasil penyebaran kuesioner staff BAAK UNIDA Gontor

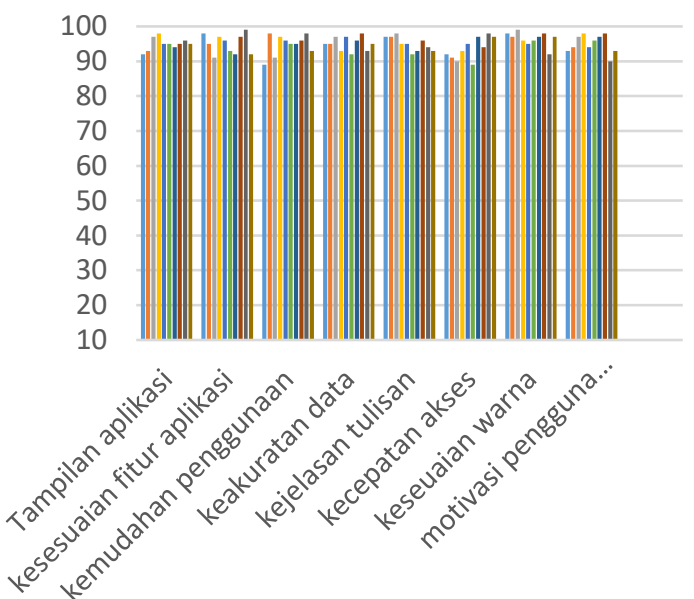

$$
\begin{array}{llll}
\square \text { MHS } 1 & \square \text { MHS 2 } & \text { MHS } 3 & \text { MHS } 4 \\
\square \text { MHS } 5 & \text { MHS 6 } & \text { MHS 7 } & \text { MHS 8 }
\end{array}
$$

Gambar 12. Penilaian mahasiswa UNIDA Gontor

Berdasarkan hasil pengujian lapangan diatas, didapatkan nilai terendah pada kecepatan akses, hal ini dapat menjadi masukan pada proses maintenance atau pemeliharaan aplikasi kedepannya. Pengujian juga dilakukan kepada calon pengguna aplikasi, yaitu dosen dan mahasiswa Universitas Darussalam Gontor yang berjumlah 10 orang, menghasilkan nilai ratarata $80 \%$ untuk dosen, dan $95 \%$ untuk mahasiswa.
Hal ini membuktikan bahwa aplikasi secara umum memiliki tingkat kesesuaian fungsi yang tinggi terhadap kebutuhan pengguna. Tampilan rekapan hasil kuesioner dosen dan mahasiswa dapat dilihat pada gambar 12 dan 13 .

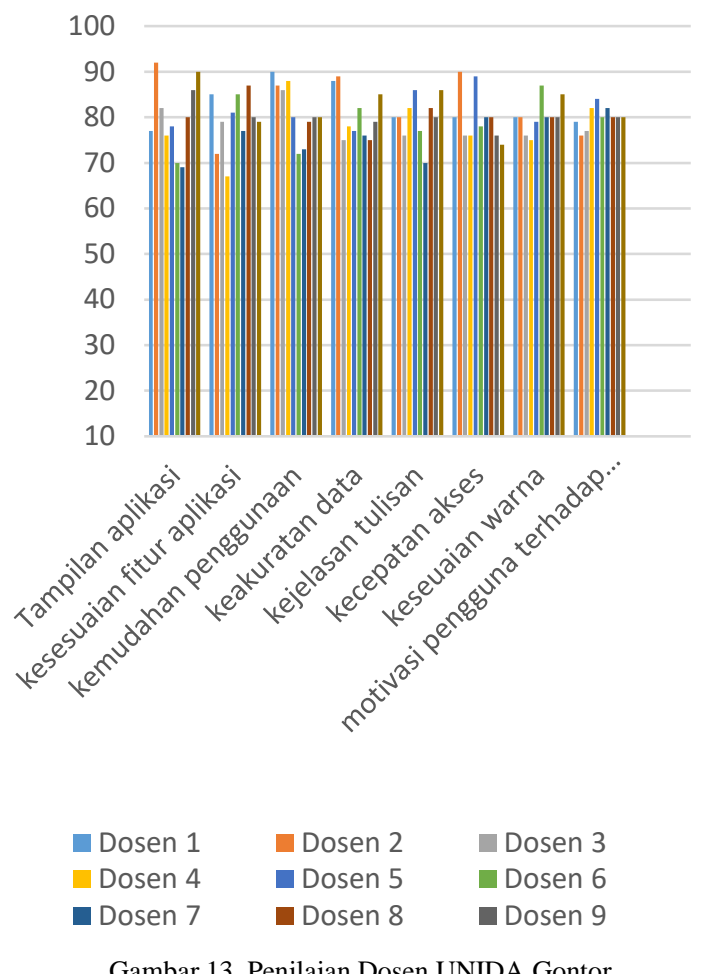

\subsection{Maintenance}

Fase terakhir adalah perbaikan beberapa kesalahan disesuaikan dengan masukan dari para calon pengguna, hingga saat ini telah dilakukan revisi aplikasi sebanyak dua kali baik dari segi tampilan, data maupun menconvert ukuran file gambar agar kecepatan akses dapat ditingkatkan, perubahan terakhir dilakukan pada 28 Juli 2020.

\section{KESIMPULAN}

Media aplikasi penunjang sistem penjadwalan perkuliahan ini sesuai dengan perangkat android dengan ukuran layar minimal 4,5 inchi serta versi android minimal android 4.4.4 KitKat. Media aplikasi penjadwalan dinilai cukup layak untuk digunakan berdasarkan hasil pengujian tingkat kesesuaian fungsi dengan kebutuhan pengguna yang menghasilkan nilai rata-rata $92 \%$ dari staff BAAK UNIDA Gontor, $80 \%$ dari para dosen, dan $95 \%$ dari mahasiswa. Namun meskipun demikian, aplikasi ini tetap berfungsi hanya sebagai media pembantu pendistribusian data dari system informasi penjadwalan perkuliahan pusat di UNIDA Gontor. Kedepanya diharapkan ada pengembangan yang dilakukan pada aplikasi yang telah ada menjadi aplikasi multiplatform, sehingga dapat diakses baik melalui perangkat berbasis android maupun IOS. 


\section{DAFTAR PUSTAKA}

[1] D. Muriyatmoko., F. R. Pradhana and Z. A. Musyafa., 2019. Durus Al-Lughah Gontory: Media Pembelajaran Bahasa Arab Untuk Pemula Menggunakan Metode Langsung 677 84

[2] A. Relawati and G. M. Zamroni, 2020 Development of Android Based Online Nurse Test Preparation 8 111-20

[3] A. Fauzan., D. Muriyatmoko and S. N. Utama, 2020, PENERAPAN TEKNOLOGI AUGMENTED REALITY ELSE ( Elementary School Education Journal ) 4 63-78

[4] T. Taufik., M. F. Alfarizi and S. Ipnuwati., 2018. "Aplikasi Penjadwalan Mata Pelajaran Sma Berbasis Web Mobile Di Sma Negeri 2 Pringsewu J. Inf. dan Komput. 6 42-8

[5] M. Muharir and N. Alamsyah., 2020., Pemanfaatan Mobile Push Notification Dalam Penyampaian Informasi Perkuliahan Mahasiswa Pada Fakultas Teknologi Informasi Berbasis Android. Technologia 11 111-8

[6] D. G. Sukmandari., 2017, Analisis Aplikasi Jadwal Perkuliahan Berbasis Android Elinvo (Electronics, Informatics, Vocat. Educ. 2 80-4

[7] Y. Bassil., 2012 A Simulation Model for the Waterfall Software Development Life Cycle 2

[8] R. Rosihan dan S. Lutfi., 2019. "Pendataan Koperasi Pada Dinas Koperasi Dan Ukm Kota Ternate Berbasis Web", JIKO (Jurnal Informatika dan Komputer), vol 1 (1), pp.13-20

[9] T. A. Ananda., N. Safriadi and A. S. Sukamto 2015 Penerapan Augmented Reality Sebagai Planet-Planet Di Tata Surya J. Sist. dan Teknol. Inf. 1 1-6

[10] R. Efendi., 2020., Rancang Bangun Aplikasi Augmented Reality Untuk Deteksi Pengenalan Tanaman Obat Berbasis Android IKRA-ITH Inform. 4 35-45

[11] D. D. W. Soejono., D. R. Candra., D. Rosandi, R. R. Putra., Y. Nurfaidzin and H. Ardiansyah., 2020, Pengujian Black Box pada Aplikasi Penjualan Berbasis Website dengan PHP MySQL Kedai Kopi.Net Menggunakan Teknik Boundary Value Analysis J. Teknol. Sist. Inf. dan Apl. 390

[12] A. Maulana., A. Kurniawan, W. Keumala., V. R. Sukma and A. Saifudin., 2020, Pengujian Black Box pada Aplikasi Penjualan Berbasis Web Menggunakan Metode Equivalents Partitions (Studi Kasus: PT Arap Store) J. Teknol. Sist. Inf. dan Apl. 350

[13] T. Hidayat \& M. Muttaqin., 2018, Pengujian Sistem Informasi Pendaftaran dan Pembayaran Wisuda Online menggunakan Black Box Testing dengan Metode Equivalence Partitioning dan Boundary Value Analysis $J$. Tek. Inform. UNIS JUTIS 6 2252-5351

[14]. P-S. Chen, dkk. 2015. Scheduling Patients' Appointments: Allocation of Healthcare Service
Using SimulationOptimization. Journal of Healthcare Engineering., vol 6(2), pp. 259-280

[15]. G. Du., X Liang dan C. Sun. 2017. Scheduling Optimization of Home Health CareService Considering Patients' Priorities andTime Windows. Sustainibility., pp. 1-22 available : https://www.mdpi.com/journal/sustainability 